\title{
Rekonstruksi Pembelajaran Kitab Kuning Untuk Mewujudkan Kemahiran Santri Dalam Memahami Kitab Kuning Di Lembaga Lajnah Bahtsul Masa-Il (LBM) AI- Mahrusiyah Putri
}

\author{
Nisrina Nur Chiari, ${ }^{1}$ Reza Ahmad Zahid ${ }^{2}$ \\ ${ }^{1}$ Institut Agama Islam Tribakti Kediri, ${ }^{2}$ Institut Agama Islam Tribakti Kediri \\ 1nisrinachiary0307@gmail.com, ${ }^{2}$ zahidrezaahmad66@gmail.com
}

\begin{abstract}
The reconstruction of the yellow book learning conducted by the Batsu Masa'il Institute (LBM) Al Mahrusiyah Putri has been implemented in the 2018-2019 school year. Even though it's only been a year, this strategy shows that it can improve the ability of female students to understand the yellow book. This is proven by the ability of female students who attend LBM to be able to translate and explain the intent contained in the yellow book. This research uses descriptive qualitative research. An illustration of the results of this study found the application of LBM Al Mahrusiyah held sifir class, tahasus, ula, wustho, and ulya. Sorogan class in the realm of reading, memurodi (translating) and understanding the yellow book. In the class of sifir and tahasus the introduction of the yellow book and nahwu shorof science. The book studied varies according to the level of study at each stage of the class.
\end{abstract}

Keywords: Learning Reconstruction, Kitab Kuning, LBM

\begin{abstract}
Abstrak
Rekonstruksi pembelajaran kitab kuning yang dilakukan Lembaga Batsu Masa'il (LBM) Al Mahrusiyah Putri sudah diterapkan Tahun ajaran 2018-2019. Meski baru satu tahun, akan tetapi strategi ini menunjukkan mampu meningkatkan kemampuan santri putri dalam memahami kitab kuning. Hal ini dibuktikan kemampuan santri putri yang mengikuti LBM mampu menerjemah dan menerangkan maksud yang terkandung dalam kitab kuning. Penelitian ini menggunakan jenis penelitian kualitatif-deskriptif. Gambaran hasil penelitian ini, ditemukan penerapan LBM Al Mahrusiyah diadakannya kelas sifir, tahasus, ula, wustho, dan ulya. Kelas sorogan dalam ranah membaca, memurodi (menterjemahkan) dan pemahaman kitab kuning. Pada kelas sifir dan tahasus pengenalan kitab kuning dan ilmu nahwu shorof. Kitab yang dikaji berfariasi sesuai dengan jenjang studi setiap tahapan kelasnya.
\end{abstract}

Kata Kunci: Rekonstruksi Pembelajaran, Kitab kuning, LBM 


\section{Pendahuluan}

Pondok pesantren merupakan lembaga pendidikan tertua di Indonesia dan merupakan hasil dari akulturasi budaya yang dilakukan oleh wali songo. Sekitar abab 1617, Syeh Maulana Malik Ibrahim memasukan budaya pendidikan Hidu-Budha ke pengajaran Agama Islam. ${ }^{1}$ Sejalan dengan perkembangan waktu, proses transfer pengetahuan menjadi pengembangan ilmu pengetahuan Islam, meskipun metode yang digunakan sebatas sorogan, ${ }^{2}$ bandongan, ${ }^{3}$ hafalan, ${ }^{4}$ dan musyawarah. ${ }^{5}$ Rujukan utamanya adalah kitab-kitab ulama klasik atau sering disebut kitab kuning. ${ }^{6}$

Hal inilah yang menjadikan pondok pesantren sebagai pemilik gelar komunitas literasi kitab kuning. ${ }^{7}$ Di beberapa pondok pesantren, pembelajaran kitab kuning awalnya dikelola langsung oleh pendirinya. Akan tetapi, sejalan dengan waktu, perkembangan jaman menuntut pengelolaan lebih modern. Hasilnya, saat ini banyak ditemukan pengelolaan pembelajaran kitab kuning melalui madrasah diniyah, lembaga batsu masa'il (LBM). Menariknya, semua kajian dalam pengelolaannya, Negara tidak melakukan intervensi. Pasalnya, lembaga-lembaga tersebut, lebih banyak membahas fiqhiyyah waqi'iyyah haditsah atau masalah fiqih faktual kontemporer yang rujukannya mennggunakan kitab klasik (kitab kuning). ${ }^{8}$

Sejatinya, seperti di pondok pesantren pada umumnya, pembelajaran kitab kuning juga dilaksanakan di pondok pesantren Al Mahrusiyah Putri Lirboyo Kota Kediri. Meskipun demikian, Al Mahrusiyah Putri Lirboyo Kota Kediri yang menjadikan LBM

1 Abdurrahman Mas'ud, Dari Haramain ke Nusantara Jejak Intelektual Arsitek Pesantren (Jakarta: Kencana Prenada Media Group, Cet. I, 2006), 56-57.

2 Ali akbar, Hidayatullah islail. "Metode Pembelajaran Kitab Kuning di Pondok Pesantren Darrun Nahdhah Thawalib Bangkinang” Al-Fikra: Jurnal Keislaman, Vol.XVII, No. 1 (Januari-Juni, 2018) h. 2132

${ }^{3}$ Al rasyid, "Pembelajaran Kitab Kuning di Pesantren Musthafawiyah, Mandailing Natal” Journal Of Contemporary Islam an Muslim Societies Vol.I, No. 1 (Januari-Juni, 2017) h. 41-67

${ }^{4}$ Akh.Syaiful Rijal, "Pemakaian Kitab Kuning dalam Meningkatkan Mutu Pembelajaran Fiqih di Madrasah Tsanawiyah Berbasis Pesantren di Pamekasan” Muslim Heritage, Vol. 1, 2 (November, 2017 April, 2018), h.293.

${ }^{5}$ Muhammad Sholeh, "kajian Kitab Thurath Berbasis Musyawarah dalam Memebentuk Tipologi Berfikir di POndok Pesantren Langitan Widang Tuban Jawa Timur” Tesis, Pascasarjana Universitas Islam Negeri Sunan Ampel Surabaya h. 1-157

6 Azuma Fela Sufa“"Efektifitas Metode Pembelajaran Kitab Kuning” Literasi , Vol. V, 2 (Desember, 2014), h.171.

7 Ali romadhoni, "Dakwah dan Tradisi Literasi di Pondok Pesantren: Studi Kasus di Pondok Pesantren Al-Anwar, Sarang, Rembang, Jawa Tengah”Jurnal Bimas Islam Vol.9. No.I 2016 h.121

${ }^{8}$ Fathur Rohman "Pembelajaran Fiqih Berbasis Masalah Melalui Kegiatan Musyawarah di Pondok Pesantren Al-Anwar Sarang Rembang”, Al-Tadzkiyyah: Jurnal Pendidikan Islam, Vol. VIII, 2 (2017), h. 184. 
dengan beberapa program-program didalamnya sebagai program unggulannya. ${ }^{9}$ Program ini dipilih berdasarkan pengelaman Madrasah Hidayatul Mubtadi'ien (MHM) Lirboyo Kota Kediri yang berhasil mencetak santri-santri memahami kitab kuning secara mendalam.

Wacana gerakan rekonstruksi dalam dunia pendidikan klasik bukan hal yang baru. Menurut Hamam Bahanudin dalam buku berjudul "Rekonstruksi Sistem Pembelajaran Pendidikan Agama Islam di Sekolah" menemukan rekonsruksi pembelajaran dilakukan dengan berpijak pada variable yang mempengaruhi pembelajaran dapat mencapai tujuan pendidikan yang diharapkan secara signifikan. Rekonstruksi ini sering dilakukan dalam pendidikan-pendidikan agama Islam yang sedang beranjak untuk mempertahankan eksistensinya tanpa mengurangi fungsi Pendidikan Agama Islam di sekolah. ${ }^{10}$

Senada dengan itu, Indriyani Ma'rifah dalam bukunya "Rekonstruksi Pendidikan Agama Islam" menemukan rekonstruksi Pendidikan Agama Islam merupakan kebutuhan mendesak. Pasalnya, rekontruksi Pendidikan Agama Islam terbukti mampu mempertahankan eksistensi lembaga penyelenggara pendidikan di tengah persaingan yang semakin ketat. Menurtnya juga, tanpa rekonstruksi, Pendidikan Agama Islam hanya menjadi tempat bertumbuhnya bibit-bibit radikalisme dan terorisme karena dia akan mengadopsi pemahaman klasik yang menjadikan peserta didik berpaham keagaman yang sangat sempit. Dia pun meyarankan, bentuk rekonstruksi yang harus dilakukan ialah Pendidikan Agama Islam. Topik yang sangat penting adalah berwawasan multicultural, karena hal tersebut menjadi sarana yang efektif menanamkan nilai-nilai toleransi dan perdamaian kepada peserta didik. ${ }^{11}$

Berdaasarkan kajian tersebut, penulis berpendapat rekonstruksi sangat dibutuhkan guna mewujudkan kemahiran santri dalam memahami kitab kuning. Selai itu, rekonstruksi juga dilakukan sebab kurangnya pelatihan membaca kitab kuning (qiroatul kutub). Sebagai bahan pembuktian terhadap kajian di atas, peneliti melakukan kajian di LBM Al Mahrusiyah Lirboyo Kota Kediri.

\section{Metode Penelitian}

${ }^{9}$ LBM PP Putri Lirboyo Al-Mahrusiyah, Progress Lajnah Bahtsul Masa-il Tahun Ajaran 20182019 (Kediri: Misykat Press), h. 10.

${ }^{10}$ Hamam Burhanudin, "Rekonstruksi Sistem Pembelajaran PAI di Sekolah", Muaddib Vol. IV, 2 (Juli-Desember, 2014), h. 90-91.

${ }^{11}$ Conference Proceedings, Annual International Conference on Islamic Studies (AICES XII) h. $241-257$ 
Metode penelitian yang digunakan dalam penelitian ini adalah penelitian kualitatif-diskriptif. Penelitian ini lebih mengedepankan mengungkaf fakta-fakta lapangan field research). Data-data yang dikumpulkan kemudian dikalrifikasi atau dikelompkkan menurut jenis, sifat dan kondisinya. Setelah itu, data dinarasikan dengan sebagai-baiknya berdasarkan paradigma penulis dan dibuatkan kesimpulan.

Sesuai dengan jenis penelitiannya, maka penelitian ini mengedepankan penggalian data secara mendalam dengan wawancara, observasi dan dokumentasi. Sedangkan sumber data lebih banyak mengunakan wawancara mendalam kepada semua pembina, pengasuh, pelaksana dan peserta kegiatan-kegiatan di LBM Al Mahrusiyah Lirboyo Kota Kediri. Di sisi lain, sebagai pembuktian dari hasil wawancara adalah penggalian dokumen-dokumen penting yang berkaitan dengan fokus penelitian.

Lokasi penelitian yakni pondok pesantren Al-mahrusiyah I, II dan III dalam kegiatan di lembaga LBM, seperti: Kelas bandongan, tahasus, sifir dan pelatihan membaca kitab (qiro'atul kutub) berupa kelas sorogan. Pemilihan lokasi ini didasarkan penerapan sistem pembelajaran seperti kelas sifir yang hanya berada di pondok AlMahrusiyah II dan diperuntukan bagi siswi kelas PK I dan II. Pemilihan lokasi pada pondok pesantren Al-Mahrusiyah I melihat dari kuantitas siswi serta penerapan metode pembelajarannya

\section{Pembahasan}

\section{Bentuk dan Dampak Rekonstruksi Pembelajaran Kitab Kuning di LBM}

\section{Pembelajaran Kitab Kuning di lembaga LBM}

Pembelajarana kitab kuning di LBM terdapat pembaharuan pada tahun ajaran 2018-2019. Pada tahun ajaran baru ini terdapat kelas sorogan, tahasus, dan sifir sebagai tempat pendalaman kitab kuning. ${ }^{12}$ Selain kelas sorogan, pembaharuan yang dilakukan LBM juga menampilkan kelas siffir dimana sebuah wadah untuk pengenalan materi nahwu shorof yang terdapat dipondok pesantren al-mahrusiyah II. ${ }^{13}$

Pembelajaran kitab kuning yang dilakukan oleh LBM sama dengan kegiatan Qiroatul kutub yang dilakukan madrasah diniyah pada tahun ajaran 2017-2018, namun pada pengelompokannya memiliki perbedaan, yakni menggunakan tes, karena dari satu kelas madrasah diniyah terdapat ketimpangan kemampuan siswi dalam memahami kitab

\footnotetext{
${ }^{12}$ Ulin Nuha, Wawancara, di teras Aula pondok pesantren putri al-mahrusiyah III ngampel barat tanggal 07 februari 2019

${ }^{13}$ Eka prasetya, Wawancara, kantor pondok Al-mahrusiyah II, 15 Januari 2019 Indonesian Journal of Islamic Education Studies (IJIES)

Volume 2, Nomor 2, Desember 2019 
kuning. ${ }^{14}$ Selain itu dalam kelas sorogan lebih mengarah pada tujuan dan mengupas tuntas ilmu nahwu dan shorofnya. ${ }^{15}$ Serta dalam kelas soroan yang diterapkan oleh LBM melihat dari cara penyampaian materi yang bervariasi, dan tidak terfokus pada satu bab. ${ }^{16}$

Serta dalam konstruk pembelajaran kitab kuning yang dilakukan LBM terdapat wadah bagi siswi yang berada ditingkat dasar, yakni kelas siffir dan tahasus. ${ }^{17}$ Konstruk pembelajaran kitab kuning yang diterapkan oleh LBM yakni terdapatnya wadah bagi siswi untuk memperdalam kitab kuning terlebih dalam praktik penerapan teori gramatika bahasa arab, kelas sesuai kemampuan, terkondisikan, lebi mencapai dari tujuan sorogan itu sendiri, serta menjadikan siswi dapat memahami isi kitab kuning.

\section{Bentuk Rekonstruksi Pembelajaran Kitab Kuning di LBM}

\section{a. Kelas Siffir}

Terkhusus kelas kelas sifir I, II dan III diperuntukan bagi santri yang bermukim di pondok pesantren al-mahrusiyah II dengan melihat kemampuan yang dimiliki. Pada setiap tingkatan memiliki standarisasi pencapaian kemampuan. Pada kelas sifir I kitab yang digunakan fasholatan dan panduan pegon dengan target kemampuan membaca dan menulis. Kelas sifir II menggunakan kitab safinah As-sholat pada materi bab ubudiyah, dengan target sorogan bisa membaca makna kitab sendiri. Mengerti tarkib, i'rob dan tanda-tandanya, penguasaan tasrif tsulasi mujarod dan bina'.

Pada kelas sifir III menggunakan kitab safinah An-naja bab ubudiyah. Dengan target sorogan kelancaran membaca, penguasaan tasrif istilahi mulai bab satu sampai enam, dan pengenalan ilmu nahwu seputar macam-macam kalimat (isim, fi'il dan huruf), serta seputar pembahasan i'rob dengan standar kitab nahwu tingkat ula. ${ }^{18}$

b. Kelas Tahasus

Penempatan kelas tahasus menggunakan data hasil uji seleksi kelas sorogan yang tidak mencapai tingkat terendah yakni kelas ula. Pada kelas tahasus dibagi menjadi dua tingkatan yakni tahasus I dan tahasus II dengan waktu pelaksanaan untuk pondok pesantren putri al-mahrusiyah I tahasus I setiap Hari Jum'at pukul 04.50-06.00 WIB. Tahasus II setiap Hari Rabu dan Jum'at pukul 20.15-21.30 WIB. Waktu dan

\footnotetext{
${ }^{14}$ Ulin Nuha, Wawancara, Teras Aula Pondok pesantren Putri Al-Mahrusiyah III, 07 Februari 2019.

${ }^{15}$ Ahmad Mudrik, Wawancara, Teras Aula Pondok pesantren Putri Al-Mahrusiyah III, 03 Februari 2019

${ }^{16}$ Muhammad Jamaluddin, Wawancara, Teras Aula Pondok pesantren Putri Al-Mahrusiyah III, 22 Feberuari 2019

${ }^{17}$ Eka Prasetya, Wawancara, Kantor Pondok Pesantren Al-Mahrusiyah II, 15 Januari 2019

${ }^{18}$ LBM PP Putri Lirboyo Al-Mahrusiyah, Progress LBM, (Kediri: Misykat Press, 2018) h.13-14
} 
pelaksanaan kelas tahasus I dan II di pondok pesantren putri Al Mahrusiyah II setiap Hari Rabu pukul 16.00-17.00 wib. Dan untuk pondok pesantren putri Al Mahrusiyah III Timur setiap Hari Senin pukul 21.15-21.30 WIB dan untuk Pondok Pesantren Putri Al Mahrusiyah III Barat setiap hari sabtu pukul 20.15- 21.30 WIB. ${ }^{19}$

Pada kelas tahasus menggunakan sistem pembelajaran kelompok dengan alokasi waktu, 10 menit pertama digunakan untuk mutholaah bersama dengan dipimpin oleh salasatu siswi disetiap kelompok. Standart kitab tahasus adalah buku panduan nahwu shorof.

Metode pembelajaran yang digunakan dalam kelas tahasus yakni Tanya jawab bagi kelas tahasus I dengan menggunakan kitab panduan nahwu sharaf. tahasus II menggunakan metode Tanya jawab dan seskali praktik membaca kitab. Kitab yang digunakan ialah kitab safinah Ash-sholah dengan target siswi bisa membaca kitab sendiri, mengerti tarkib, i'rob, dan tanda-tandanya bina'.

Selain itu, pembelajaran dalam kelas tahasus dengan cara ustadzah/penyimak dianjurkan memberikan tugas dan hafalan dengan menyesuaikan kemampuan siswi dan diadakan evaluasi kelulusan satu kali dalam setahun.

Terkusus untuk kelas tahasus berhak mendapatkan sertifikat kelulusan kemudian melanjutkan ketingkat sorogan setelah mengikuti bimbingan tahasus minimal satu tahun, telah lulus dalam ujian lisan dan tulisan serta mendapatkan rekomendasi dari ustadz. ${ }^{20}$

c. Kelas Sorogan

Sorogan kitab dibagi menjadi 3 kelas yakni: kelas ula, wustho, dan ulya. Waktu pelaksanaan sorogan kitab untuk Pondok Pesantren Putri Al Mahrusiyah I setiap Hari Rabu dan Jum'at pukul 20.15-21.30 WIB Waktu untuk Pondok Pesantren Putri Al Mahrusiyah II pada Hari Sabtu dan Minggu pukul 16.00-17.00 WIB dan untuk Pondok Pesantren Putri Al Mahrusiyah III pada Hari Senin dan Sabtu pukul 20.15-21.30 WIB. ${ }^{21}$

Pada kelas sorogan ini menggunakan sistem pembelajaran kelompok setiap kelompok maksimal 25 orang. Dengan cara siswi membaca dan memurodi dihadapan penyimak kemudian penyimak mengajukan pertanyaan seputar nahwu, shorof serta murod dengan standar kitab nahwu tingkatan sorogan masing-masing. Pada kelas ini

\footnotetext{
${ }^{19}$ LBM PP Putri Lirboyo Al-Mahrusiyah, Progress LBM, h.11

${ }^{20}$ LBM PP Putri Lirboyo Al-Mahrusiyah, h.18

${ }^{21}$ LBM PP Putri Lirboyo Al-Mahrusiyah, h.13-14
} 
penyimak/pengajar dinjurkan memberikan tugas dan hafalan dalam waktu yang berbeda dengan melihat kemampuan siswi. Serta dilakukan evaluasi kenaikan sesuai tingkatnya dalam satu tahun sekali.

Untuk menentukan tingkat kelas sorogan kitab, menggunakan ujian seleksi bagi seluruh santri dengan ketentuan yang sudah ditetapkan. Standar pencapaian seorang santri dikatakan masuk kelas ula yaitu: lancar dan benar membaca kitab safinatun najah, serta memiliki pengetahuan dan kemampuan seputar pokok dasar ilmu nahwu dan shorof. Standar pencapaian seorang santri dikatakan masuk kelas wustho yaitu: lancar dan benar membaca kitab takrib tanpa makna bab ubudiyah. Mampu mengaplikasikan standar nahwu dan shorof kedalam bacaan secara global dan mendalam, serta bisa memurodi dan menerangkan maksud dari redaksi yang dibaca.

Standar pencapaian seorang santri dikatakan masuk kelas ulya yaitu: lancar dan benar membaca Kitab Fathul Qorib tanpa makna bab muamalah, mampu mengaplikasikan standar nahwu dan shorof kedalam bacaan secara global dan mendalam beserta dalilnya, mampu mengi'robi kalimat menggunakan bahasa arab dan mampu mendeskripsikan redaksi yang telah dibaca kedalam masalah yang aktual dan faktual. $^{22}$

Proses pembelajaran kitab kuning pada kelas sorogan sebagai berikut:

1) Kelas Ula

Pada tingkat ula menggunakan kitab Safinah An-Naja tanpa makna bab ubudiyah dengan target sorogan kelancaran membaca, penguasaan tasrif istilahi bab satu sampai enam, dan standar nahwu seputar macam-macam kalimat (isim, fi'il, dan huruf), pembahasan i'rob (marfuatul asma', manshubatul asma' dan mahfudotul asma') dengan standar kitab jurumiyah.

2) Kelas Wustho

Pada tingkat wustho menggunakan kitab takrib bab ubudiyah dengan target sorogan kelancaran membaca dan murod, penerapan ilmu nahwu (tarkib, ta'rif dasar dan bagian dari tarkib i'rob) dengan standar kitab nahwu tingkat wustho. Dan pemahaman ilmu shorof ditekankan pada teori dasar tasrif istilahi dan lughawi serta mencoba mentasrif dan mengi'lal.

3) Kelas Ulya

${ }^{22}$ LBM PP Putri Lirboyo Al-Mahrusiyah, h.11-13 
Pada tingkat ulya menggunakan Kitab Fathul Qorib bab ubudiyah dengan target sorogan kelancaran membaca pemahaman/syarah, penguasaan dan penerapan nahwu seputar tarkib yang lebih spesifik untuk memahami murod, ta'rif lengkap, sekaligus pembagian i'rob keseluruhan serta hal-hal yang terkait dengan permasalahan furu'iyyah. Dengan standar kitab nahwu tingkat Ulya. Serta penguasaan penerapan ilmu shorof seputar tasrif istilahi dan lughowi meliputi dalil, faidah dan mentasrif beserta dalilnya.

\section{Dampak Rekonstruksi Pembelajran Kitab Kuning di LBM}

Dalam setiap perubahan yang dilakukan pasti memiliki dampak, baik itu positif maupun negatif. Dampak yang dirasakan sebab adanya rekonstruksi pembelajaran kitab kuning di LBM. Lebih tertata karena sesuai dengan kemampuan siswi. ${ }^{23}$ Selain itu dampak yang dirasa akan adanya konstruk pembelajaran kitab kuning yang baru ini ialah terwujudnya pemahaman santri terhadap kitab kuning. ${ }^{24}$ Dampak yang dirasa selain yang diatas ialah terlatihnya siswi dalam mempraktikan ilmu nahwu dan shorof. ${ }^{25}$ dari perubahan yang dilakakan LBM dalam proses permbelajaran kitab kuning ialah memberikan siswi modal memahami kitab kuning. ${ }^{26}$

Dari hasil wawancara ada dua pendapat mengenai keberhasilan program sorogan yang merupakan bentuk rekonstruksi pembelajaran di LBM menurut salah satu dari dewan rois LBM mengatakan bahwa program sorogan ini belum bisa membantu santri dalam memahami kitab kuning, akan tetapi arah pada tahap tersebut sudah terlihat dan jelas. ${ }^{27}$ Pendapat yang lain muncul dari salah satu penyimak (guru) dalam kelas sorogan menurutnya program ini sudah berhasil memjadikan siswi faham terhadap kitab kuning. ${ }^{28}$ Pendapat ini didukung oleh salasatu pengajar sorogan kelas wustho yang menyatakan bahwa kelas sorogan bisa menjadikan siswi mahir dalam memahami kitab kuning dari segi nahwu shorofnya serta fiqihnya. ${ }^{29}$

\footnotetext{
${ }^{23}$ Ahmad Mudrik, Wawancara, di Teras aula pondok pesantren putri al-mahrusiyah III ngampel barat tanggal 03 februari 2019

${ }^{24}$ Ulin Nuha, Wawancara, Teras Aula Pondok pesantren Putri Al-Mahrusiyah III, 07 Februari 2019.

${ }^{25}$ Muhammad Jamaluddin, Wawancara, Teras Aula Pondok pesantren Putri Al-Mahrusiyah III, 22 Feberuari 2019

${ }^{26}$ Muhammad Jamaluddin, Wawancara, Teras Aula Pondok pesantren Putri Al-Mahrusiyah III, 22 Feberuari 2019

${ }^{27}$ Muhammad Jamaluddin, Wawancara, Teras Aula Pondok pesantren Putri Al-Mahrusiyah III, 22 Feberuari 2019

${ }^{28}$ Ulin Nuha, Wawancara, Teras Aula Pondok pesantren Putri Al-Mahrusiyah III, 07 Februari 2019.

${ }^{29}$ Ahmad Mudrik, Wawancara, di Teras aula pondok pesantren putri al-mahrusiyah III ngampel barat tanggal 03 februari 2019
} 
Melihat dari hasil wawancara, observasi dan buku petunjuk pelaksanaan dapat dikolaborasi yang berhasil disimpulkan dampak dari rekonstruksi pembelajaran kitab kuning yang dilakukan di LBM. Dampak adanya kelas siffir, menjadikan siswi yang faham materi (teori nahwu shorof), kelas tahasus menciptakan siswi yang siap untuk memasuki kelas sorogan Ula. Pada kelas sorogan Ula, wustho dan Ulya melatih siswi untuk menerapkan teori nahwu shorof pada kitab kuning dengan cara membacanya, selain itu dampak yang dirasa yakni siswi dapat memahami kitab kuning.

Tahapan yang diterapkan oleh LBM sudah mencakup dari berbagai kelas dengan pembagian dan pencapaiannya. Dengan adanya praktik dan evaluasi secara berkala melatih siswi untuk belajar membaca, memurodi (menterjemahkan) serta memahami isi kitab kuning.

\section{Kesimpulan}

Hasil penelitian yang telah dilakukan dapat ditarik kesimpulan bahwa lembaga LBM telah melakukan gebrakan baru ditahun ajaran 2018-2019 terlebih pada konstruk pembelajaran kitab kuning. Berdasarkan teori dan hasil penelitian yang telah dilakukan dapat ditarik kesimpulan sebagai berikut:

Pertama, bentuk rekonstruksi pembelajaran kitab kuning yang dilakukan di lembaga LBM ialah diadakannya kelas sifir, tahasus, ula, wustho, dan ulya dengan pencapaian kemampuan sesuai dengan tingkatannya masing-masing. Kelas sorogan dalam ranah membaca, memurodi (menterjemahkan) dan pemahaman kitab kuning. Pada kelas sifir dan tahasus pengenalan kitab kuning dan ilmu nahwu shorof.

Kedua, dampak dari rekonstruksi pembelajaran yang dilakukan lembaga LBM ialah kemampuan siswi pada kitab kuning lebih mendalam sesuai dengan target pencapaiannya. Terlebih pada sektor pembelajaran kitab kuning lembaga LBM sangat berdampak pada keberhasilan santri, baik dalam tingkat membaca, memurodi (menterjemah) sampai pemahaman.

\section{Daftar Pustaka}

al Rasyid, "Pembelajaran Kitab Kuning di Pesantren Musthafawiyah, Mandailing Natal" Journal Of Contemporary Islam an Muslim Societies Vol.I, No. 1, JanuariJuni, 2017

Ali Akbar, Hidayatullah Ismail. "Metode Pembelajaran Kitab Kuning di Pondok Pesantren Darrun Nahdhah Thawalib Bangkinang" Al-Fikra: Jurnal Keislaman, Vol.XVII, No. 1, Januari-Juni, 2018 
Burhanudin, Hamam. "Rekonstruksi Sistem Pembelajaran PAI di Sekolah", Muaddib Vol. IV, 2, Juli-Desember, 2014

Conference Proceedings, Annual International Conference on Islamic Studies, AICES XII

Fathur Rohman "Pembelajaran Fiqih Berbasis Masalah Melalui Kegiatan Musyawarah di Pondok Pesantren Al-Anwar Sarang Rembang", Al-Tadzkiyyah: Jurnal Pendidikan Islam, Vol. VIII, 2, 2017

LBM PP Putri Lirboyo Al-Mahrusiyah, Progress Lajnah Bahtsul Masa-il Tahun Ajaran 2018-2019, Kediri: Misykat Press

Mas'ud, Abdurrahman. Dari Haramain ke Nusantara Jejak Intelektual Arsitek Pesantren Jakarta: Kencana Prenada Media Group, Cet. I, 2006

Rijal, Akh. Syaiful "Pemakaian Kitab Kuning dalam Meningkatkan Mutu Pembelajaran Fiqih di Madrasah Tsanawiyah Berbasis Pesantren di Pamekasan" Muslim Heritage, Vol. 1, 2, November, 2017 - April, 2018

Romadhoni, Ali. "Dakwah dan Tradisi Literasi di Pondok Pesantren: Studi Kasus di Pondok Pesantren Al-Anwar, Sarang, Rembang, Jawa Tengah" Jurnal Bimas Islam Vol.9. No.I 2016

Sholeh, Muhammad. "Kajian Kitab Thurath Berbasis Musyawarah dalam Memebentuk Tipologi Berfikir di Pondok Pesantren Langitan Widang Tuban Jawa Timur" Tesis, Pascasarjana Universitas Islam Negeri Sunan Ampel Surabaya

Sufa, Azuma Fela. "Efektifitas Metode Pembelajaran Kitab Kuning” Literasi, Vol. V, 2, Desember, 2014

Ziemek, Manfred. Pesantren Dalam Perubahan Sosial, terj. Butche B. Soendjojo, cet I. Jakarta : P3M, 1986 